\title{
Improving nitrogen balance with irrigation practice and cropping system
}

\author{
U.M. Sainju
}

\begin{abstract}
Nitrogen $(\mathrm{N})$ balance based on $\mathrm{N}$ inputs, outputs, and retention in the soil shows $\mathrm{N}$ flows that measure agroecosystem performance and environmental sustainability. Complexity of measurements of some parameters and constraints on time, labor, and cost have resulted in limited studies on $\mathrm{N}$ balance in agroecosystems. The objective of this study was to measure $\mathrm{N}$ balance based on $\mathrm{N}$ inputs and outputs and soil $\mathrm{N}$ retention in response to irrigation and cropping system from 2006 to 2011 in the northern Great Plains. Treatments were two irrigation practices (irrigated versus nonirrigated) as the main plot and five cropping systems (conventional till barley [Hordeum vulgare $\mathrm{L}$.] with $\mathrm{N}$ fertilizer [CTBN], conventional till barley without $\mathrm{N}$ fertilizer [CTBO], no-till barley-pea [Pisum sativum L.] with N fertilizer [NTB$\mathrm{P}]$, no-till barley with $\mathrm{N}$ fertilizer [NTBN], and no-till barley without $\mathrm{N}$ fertilizer [NTBO]) as the split plot treatment arranged in a randomized block design with three replications. Compared with other cropping systems, total $\mathrm{N}$ input due to $\mathrm{N}$ fertilization, pea $\mathrm{N}$ fixation, soil $\mathrm{N}$ mineralization, atmospheric $\mathrm{N}$ deposition, crop seed $\mathrm{N}$, and nonsymbiotic $\mathrm{N}$ fixation was $15 \%$ to $64 \%$ greater with NTB-P in the irrigated practice and $32 \%$ to $69 \%$ greater in the nonirrigated practice. Compared with $\mathrm{CTBO}$ and $\mathrm{NTBO}$, total $\mathrm{N}$ output due to grain $\mathrm{N}$ removal, denitrification, volatilization, plant senescence, $\mathrm{N}$ leaching, gaseous $\mathrm{N}(\mathrm{NO}$ ) emissions, and surface runoff was $66 \%$ to $74 \%$ greater with NTB-P, CTBN, and NTBN in the irrigated practice and $46 \%$ to $53 \%$ greater in the nonirrigated practice. Nitrogen sequestration rate at the 0 to $10 \mathrm{~cm}$ depth varied from $6 \mathrm{~kg} \mathrm{~N} \mathrm{ha}^{-1} \mathrm{y}^{-1}$ with irrigated CTBO to $37 \mathrm{~kg} \mathrm{~N} \mathrm{ha}^{-1}$ $\mathrm{y}^{-1}$ with irrigated NTBN and nonirrigated NTB-P. Nitrogen balance ranged from $-54 \mathrm{~kg} \mathrm{~N}$ $\mathrm{ha}^{-1} \mathrm{y}^{-1}$ with nonirrigated NTBN to $30 \mathrm{~kg} \mathrm{~N}^{-1} \mathrm{y}^{-1}$ with irrigated NTB-P, with greater $\mathrm{N}$ surplus for irrigated NTB-P and lower N deficit for nonirrigated NTB-P. The NTB-P can sustain agronomic performance due to similar grain $\mathrm{N}$ removal and enhance environmental sustainability due to decreased $\mathrm{N}$ loss to the environment while reducing external $\mathrm{N}$ inputs, regardless of irrigation practices.
\end{abstract}

Key words: crop rotation-irrigation—nitrogen fertilization-nutrient cycling-soil fertility-tillage

\begin{abstract}
Nitrogen (N) lost to the environment through leaching, denitrification, volatilization, surface runoff, soil erosion, and nitrous oxide $\left(\mathrm{N}_{2} \mathrm{O}\right)$ emissions as a result of excessive $\mathbf{N}$ fertilization to crops is a major problem that can result in health hazards to human beings and animals, lake eutrophication, and global warming (Smil 1999; Janzen et al. 2003; Eickhout et al. 2006; Ross et al. 2008). This results because $N$ is a major nutrient, which is required by plants in large amounts (Janzen et al. 2003; Eickhout et al. 2006). As crops can remove about $40 \%$ to $60 \%$ of applied $N$ (Meisinger and Randall 1991; Schepers and Mosier 1991;
\end{abstract} Peterson 1990). Excessive $N$ fertilization also reduces crop yields and degrades soil quality by increasing acidification (Franzluebbers 2007; Herrero et al. 2010). Therefore, improved management practices are needed to increase $\mathrm{N}$-use efficiency, reduce $\mathrm{N}$ loss to the environment and $\mathrm{N}$ fertilization rates, and sustain crop yields and $\mathrm{N}$ uptake (Janzen et al. 2003; Ross et al. 2008; Pieri et al. 2011; Sainju et al. 2012, 2014).

Nitrogen can also be added to the soil from irrigation water, dry and wet (snow and rain) depositions from the atmosphere, biological $\mathrm{N}$ fixation, soil $\mathrm{N}$ mineralization, nonsymbiotic $\mathrm{N}$ fixation, and crop seeds (Janzen et al. 2003; Ross et al. 2008; Pieri et al. 2011). Nitrogen can be removed from the agroecosystem through grain and biomass harvest and lost to the environment through various processes as described above. The unharvested $\mathrm{N}$ in crop residue and roots can transform to soil $\mathrm{N}$ storage. Some of the applied $\mathrm{N}$ through manures and fertilizers can also convert into soil organic $\mathrm{N}$. An account of all $\mathrm{N}$ inputs and outputs and $\mathrm{N}$ retention in the soil in the agroecosystem can provide $\mathrm{N}$ balance, which documents dominant processes of $\mathrm{N}$ flow and measures agronomic performance and environmental sustainability (Watson and Atkinson 1999; Ross et al. 2008).

Because of the presence of soil residual $\mathrm{N}, \mathrm{N}$ fertilization rates to crops are usually adjusted by deducting soil residual $\mathrm{N}$ at planting and $\mathrm{N}$ mineralization during the crop growing season from recommended $\mathrm{N}$ rates so that crop production and $\mathrm{N}$-use efficiency can be maximized and the potential for $\mathrm{N}$ losses minimized (Janzen et al. 2003; Ross et al. 2008; Sainju et al. 2012, 2014). As it is not possible to determine soil $\mathrm{N}$ mineralization at crop planting due to the long time required for determination, it is estimated that about $1 \%$ of soil organic $\mathrm{N}$ to a depth of $30 \mathrm{~cm}$ in dryland cropping systems to $2 \%$ in irrigated cropping systems is mineralized every year, depending on soil temperature and water content, residue addition (fresh or old residue), and soil organic matter (Schepers and Mosier 1991; Wang et al. 2014). As a result, $\mathrm{N}$ fertilization rates to same crops or different crops, as determined by economical profitability rather than maximum crop yields, vary with soil and climatic conditions, nutrient supply, and competitions with weeds and pests (Schepers and Mosier 1991).

Differences in $\mathrm{N}$ inputs, outputs, and retention in the soil due to variations in soil
Upendra M. Sainju is a research soil scientist at USDA Agricultural Research Service, Northern Plains Agricultural Research Laboratory, Sidney, Montana. 
and climatic conditions, crop species, and management practices can affect $\mathrm{N}$ balance (Meisinger and Randall 1991; Ross et al. 2008; Pieri et al. 2011). Nitrogen fertilization rates and losses can be lower in fine- than coarse-textured soils due to increased soil $\mathrm{N}$ retention, although gaseous emissions and $\mathrm{N}$ leaching could be greater in fine- and coarse-textured soils, respectively (Meisinger and Randall 1991; Schepers and Mosier 1991; Wang et al. 2014). Some researchers (Ross et al. 2008; Sainju et al. 2016) have reported that legume-based cropping systems have $\mathrm{N}$ surplus due to reduced external $\mathrm{N}$ inputs as a result of legume $\mathrm{N}$ fixation and lower $\mathrm{N}$ loss to the environment compared with nonlegume monocropping. Others (Sainju et al. 2018) have found that tillage and cultural practices had no effect on dryland agroecosystem $\mathrm{N}$ balance.

Some studies on $\mathrm{N}$ balance in agroecosystems with various cropping systems have been reported in long-term experiments (Davis et al. 2003; Ross et al. 2008; Pieri et al. 2011). Limited information, however, exists on the effect of various management practices, such as irrigation, tillage, crop rotation, cropping system, and $\mathrm{N}$ fertilization, on $\mathrm{N}$ balance in the northern Great Plains, United States. Difficulty and complexity of measuring some $\mathrm{N}$ inputs and outputs, the need for longterm experiments to reach equilibrium, and increased time, labor, and cost constraints have resulted on limited studies on $\mathrm{N}$ balance. As a result, some parameters have to be estimated from the literature, which add uncertainty to the calculation of $\mathrm{N}$ balance values.

This study examined the effect of irrigation practice and cropping system on $\mathrm{N}$ flows in the soil-plant-water-air continuum and $\mathrm{N}$ balance in the agroecosystem from 2006 to 2011 in western North Dakota, United States. The objectives of this study were to (1) evaluate the effect of irrigation, tillage, crop rotation, and $\mathrm{N}$ fertilization on $\mathrm{N}$ flows in crops, soil, and the environment; (2) quantify $\mathrm{N}$ balance based on $\mathrm{N}$ inputs, outputs, and changes in soil $\mathrm{N}$ retention; and (3) determine improved management practices that optimize $\mathrm{N}$ balance, reduce $\mathrm{N}$ fertilization rate, enhance crop $\mathrm{N}$ uptake, and sustain environmental quality. My hypothesis was that no-till barley (Hordeum vulgare L.)-pea (Pisum sativum L.) rotation with reduced $\mathrm{N}$ rate would enhance agronomic performance and environmental sustainability by providing favorable $\mathrm{N}$ balance due to enhanced crop $\mathrm{N}$ uptake, reduce external $\mathrm{N}$ input and $\mathrm{N}$ loss to the environment, and increase soil $\mathrm{N}$ retention compared to conventional till continuous barley with or without irrigation.

\section{Materials and Methods}

Field Experiment. The study was conducted from 2006 to 2011 in Nesson Valley (48.1 ${ }^{\circ}$ $\left.\mathrm{N}, 103.1^{\circ} \mathrm{W}\right)$, western North Dakota, where average air temperature (59-year average) ranged from $-5^{\circ} \mathrm{C}$ in January to $32^{\circ} \mathrm{C}$ in July through August and annual precipitation was $373 \mathrm{~mm}$. At the site, the soil, a Lihen sandy loam (sandy, mixed, frigid, Entic Haplustoll), had $720 \mathrm{~g} \mathrm{~kg}^{-1}$ sand, $120 \mathrm{~g} \mathrm{~kg}^{-1}$ silt, $160 \mathrm{~g}$ $\mathrm{kg}^{-1}$ clay, and $7.7 \mathrm{pH}$ at the 0 to $10 \mathrm{~cm}$ depth before the initiation of the experiment in April of 2006. At the same time and depth, soil organic carbon (C) was $14.2 \mathrm{Mg} \mathrm{C}^{-1}$ and total $\mathrm{N} 1.38 \mathrm{Mg} \mathrm{N} \mathrm{ha}^{-1}$. Previous vegetation at the site for the last 24 years was a mixture of alfalfa (Medicago sativa L.), crested wheatgrass (Agropyron cristatum [L.] Gaertn), and western wheatgrass (Pascopyrum smithii [Rydb.] A. Love), which were killed by applying glyphosate (N-[phosphonomethyl] glycine]) at $3.5 \mathrm{~kg}$ active ingredient $\mathrm{ha}^{-1}$.

The experimental design was a randomized complete block in a split plot arrangement with three replications. Mainplot treatment included two irrigation practices (irrigated versus nonirrigated) and the split-plot treatment was six cropping systems (conventional-till malt barley with 67 to $134 \mathrm{~kg} \mathrm{~N} \mathrm{ha}^{-1}$ [CTBN], conventional-till malt barley with $0 \mathrm{~kg} \mathrm{~N} \mathrm{ha}^{-1}$ [CTBO], no-till malt barley-pea with 67 to $134 \mathrm{~kg} \mathrm{~N}$ ha $^{-1}$ [NTB-P], no-till malt barley with 67 to 134 $\mathrm{kg} \mathrm{N} \mathrm{ha}{ }^{-1}$ [NTBN], and no-till malt barley with $0 \mathrm{~kg} \mathrm{~N} \mathrm{ha}{ }^{-1}$ [NTBO]). All cropping systems had malt barley as one crop phase, except in NTB-P, which had two phases (malt barley and pea) of the crop rotation present in every year. The conventional cropping system was CTBN in both irrigated and nonirrigated practices. Malt barley received recommended $\mathrm{N}$ fertilization rates of 134 and $67 \mathrm{~kg} \mathrm{~N} \mathrm{ha}^{-1}$ in the irrigated and nonirrigated practices, respectively. Nitrogen rates for irrigated and nonirrigated malt barley varied because of the differences in grain yields and $\mathrm{N}$ uptake by barley in irrigated and nonirrigated conditions. Nitrogen rates were adjusted to residual soil $\mathrm{NO}_{3}-\mathrm{N}$ content to a depth of $60 \mathrm{~cm}$ in samples collected after crop harvest in the autumn of the pre- vious year to reduce over fertilization. No N fertilizer was applied to pea.

Tillage in CTBN and CTBO plots was conducted using a rototiller and a single-pass field cultivator to a depth of 10 $\mathrm{cm}$. The NTBN and NTBO plots were left undisturbed, except during planting and fertilization in rows. Malt barley and pea were planted using a no-till drill that also banded $\mathrm{N}$ fertilizer to a depth of $5 \mathrm{~cm}, 2.5 \mathrm{~cm}$ away from the seed row. The size of the main plot was $21.0 \times 10.6 \mathrm{~m}$ and the split plot was 3.0 $\times 10.6 \mathrm{~m}$.

Malt barley (cv. Tradition, Busch Agricultural Resources, Fargo, North Dakota) was planted at the $3.8 \mathrm{~cm}$ depth at $90 \mathrm{~kg} \mathrm{ha}^{-1}$ in the irrigated treatment and at $67 \mathrm{~kg} \mathrm{ha}^{-1}$ in the nonirrigated treatment in late April, 2006 to 2011. At the same time, pea (cv. Majoret, Macintosh Seed, Havre, Montana) was planted at $200 \mathrm{~kg} \mathrm{ha}^{-1}$ in irrigated and nonirrigated treatments. Half of the $\mathrm{N}$ fertilizer as urea (or $67 \mathrm{~kg} \mathrm{~N} \mathrm{ha}^{-1}$ ) was banded at planting and the other half was broadcast at four weeks after planting in irrigated malt barley. In nonirrigated malt barley, all $\mathrm{N}$ fertilizer was banded at planting. For both irrigated and nonirrigated malt barley and pea, phosphorus (P) fertilizer (as triple super phosphate $[45 \% \mathrm{P}]$ at $25 \mathrm{~kg} \mathrm{P} \mathrm{ha}^{-1}$ ) and potassium (K) fertilizer (as muriate of potash $[52 \% \mathrm{~K}]$ at $21 \mathrm{~kg} \mathrm{~K} \mathrm{ha}^{-1}$ ) were banded at planting. To control weeds and pests, appropriate types and amounts of herbicides and pesticides were applied during growth and after crop harvest. In irrigated treatments, water was applied from 10 to $34 \mathrm{~mm}$ per application for a total of 47 to $236 \mathrm{~mm}$ from 2006 to 2011 using a self-propelled irrigation system based on soil water content and crop demand. Malt barley and pea grain yields were determined by harvesting grains from an area of $10.6 \times 1.5 \mathrm{~m}$ using a plot combine and adjusting the yield on oven-dried basis at $60^{\circ} \mathrm{C}$ for three days in late July and early August, 2006 to 2011. Two days before grain harvest, biomass yield was determined by harvesting biomass (leaves + stems) after separating grains from two $0.5 \mathrm{~m}^{2}$ areas per plot outside yield rows, oven drying at $60^{\circ} \mathrm{C}$ for three days, and weighing. After grain harvest, crop residue as biomass of malt barley and pea was returned to the soil.

Soil samples were collected at the 0 to 10 $\mathrm{cm}$ depth before the initiation of the experiment in April of 2006 and after the end of the experiment in September of 2011. Samples 
were collected using a hand probe $(2.5 \mathrm{~cm}$ inside diameter) from five random locations within the plot, composited, air dried, and ground to $2 \mathrm{~mm}$. A subsample (10 g) was oven dried at $110^{\circ} \mathrm{C}$ for 24 hours to determine dry weight, from which the bulk density was calculated by dividing the weight of the ovendried soil by the volume of the core.

Laboratory Analysis. Nitrogen concentration $\left(\mathrm{g} \mathrm{N} \mathrm{kg}^{-1}\right)$ in crop grain and biomass was determined using a high combustion $\mathrm{C}$ and $\mathrm{N}$ analyzer (LECO Corp., St Joseph, Michigan). Nitrogen removal in grain and crop residue $\mathrm{N}\left(\mathrm{kg} \mathrm{N} \mathrm{ha}^{-1}\right)$ returned to the soil were calculated by multiplying grain and biomass yields by their $\mathrm{N}$ concentration. Total aboveground biomass $\mathrm{N}$ was calculated as the sum of grain $\mathrm{N}$ removal and crop residue $\mathrm{N}$.

Soil total $\mathrm{N}$ concentration $\left(\mathrm{g} \mathrm{N} \mathrm{kg}^{-1}\right)$ was determined by using the $\mathrm{C}$ and $\mathrm{N}$ analyzer as above after grinding the soil samples to $<0.5$ $\mathrm{mm}$. Soil total $\mathrm{N}$ content $\left(\mathrm{Mg} \mathrm{N} \mathrm{ha}{ }^{-1}\right)$ was calculated by multiplying total $\mathrm{N}$ concentration by the bulk density and the thickness of the soil layer. Soil bulk density at 0 to 10 $\mathrm{cm}$ was not different among treatments at the beginning and end of the experiment and averaged $1.13( \pm 0.02)$ and $1.16( \pm 0.04) \mathrm{Mg}$ $\mathrm{m}^{-3}$ in 2006 and 2011, respectively.

Nitrogen Balance. Total $\mathrm{N}$ input $\left(\mathrm{N}_{\mathrm{ti}}\right)$ was calculated as

$\mathrm{N}_{\mathrm{ti}}=\mathrm{N}_{\mathrm{a}}+\mathrm{N}_{\mathrm{b}}+\mathrm{N}_{\mathrm{c}}+\mathrm{N}_{\mathrm{d}}+\mathrm{N}_{\mathrm{e}}+\mathrm{N}_{\mathrm{f}}$

where $\mathrm{N}_{\mathrm{a}}=\mathrm{N}$ fertilization rate, $\mathrm{N}_{\mathrm{b}}=$ biological $\mathrm{N}$ fixation, $\mathrm{N}_{\mathrm{c}}=$ soil $\mathrm{N}$ mineralization, $\mathrm{N}_{\mathrm{d}}=$ atmospheric $\mathrm{N}$ deposition, $\mathrm{N}_{\mathrm{e}}=\mathrm{N}$ added by crop seeds, and $\mathrm{N}_{\mathrm{f}}=$ nonsymbiotic $\mathrm{N}$ fixation. Biological $\mathrm{N}$ fixed by pea $\left(\mathrm{N}_{\mathrm{b}}\right)$ was calculated as

$\mathrm{N}_{\mathrm{b}}=0.7 \times$ (aboveground pea biomass $\mathrm{N}+$ $0.33 \times$ total pea aboveground biomass $N$ ), (2)

where 0.7 is the conversion factor for $\mathrm{N}$ fixed by pea, assuming that $70 \%$ of $\mathrm{N}$ is fixed by legumes and $30 \%$ is taken up from the soil (Meisinger and Randall 1991; Ross et al. 2008; Pieri et al. 2011). Assuming that belowground biomass $\mathrm{N}$ constitutes about one-third of the total aboveground biomass $\mathrm{N}$, the value $0.33 \times$ total pea aboveground biomass $\mathrm{N}$ refers to the estimated belowground biomass $\mathrm{N}$ when $\mathrm{N}$ is not measured (Meisinger and Randall 1991). As I did not measure belowground biomass N, I calculated this value using equation 2 . I estimated
$\mathrm{N}$ mineralization $\left(\mathrm{N}_{\mathrm{c}}\right)$ from crop residue and soil as $2 \%$ of soil total $\mathrm{N}$ content for all cropping systems in the irrigated practice and $1 \%$ in the nonirrigated practice (Schepers and Mosier 1991). Nitrogen from atmospheric deposition $\left(\mathrm{N}_{\mathrm{d}}\right)$ included both wet (rain and snow) and dry (absorption of ammonia $\left[\mathrm{NH}_{3}\right]$ and other compounds by the field from the atmosphere) depositions, and each was estimated as $7 \mathrm{~kg} \mathrm{~N} \mathrm{ha}^{-1} \mathrm{y}^{-1}$ (Meisinger and Randall 1991; Ross et al.2008). Nitrogen added from crop seeds $\left(\mathrm{N}_{\mathrm{e}}\right)$ was calculated by multiplying the seed rate by $\mathrm{N}$ concentration. In NTB-P, $\mathrm{N}$ added from malt barley and pea seeds was determined by averaging $\mathrm{N}$ added from each crop seed. Nitrogen added from nonsymbiotic $\mathrm{N}$ fixation $\left(\mathrm{N}_{\mathrm{f}}\right)$ by blue-green algae and free-living soil bacteria was estimated as $5 \mathrm{~kg} \mathrm{~N} \mathrm{ha}^{-1} \mathrm{y}^{-1}$ (Stevenson 1982; Ross et al. 2008).

Total $\mathrm{N}$ output $\left(\mathrm{N}_{\mathrm{to}}\right)$ was calculated as

$\mathrm{N}_{\mathrm{to}}=\mathrm{N}_{\mathrm{g}}+\mathrm{N}_{\mathrm{h}}+\mathrm{N}_{\mathrm{i}}+\mathrm{N}_{\mathrm{j}}+\mathrm{N}_{\mathrm{k}}+\mathrm{N}_{\mathrm{l}}+\mathrm{N}_{\mathrm{m}}$, (3)

where $\mathrm{N}_{\mathrm{g}}=$ crop grain $\mathrm{N}$ removal, $\mathrm{N}_{\mathrm{h}}=$ $\mathrm{N}$ loss through $\mathrm{NH}_{3}$ volatilization, $\mathrm{N}_{\mathrm{i}}=$ denitrification $\mathrm{N}$ loss, $\mathrm{N}_{\mathrm{j}}=\mathrm{N}$ loss during plant senescence, $\mathrm{N}_{\mathrm{k}}=\mathrm{N}$ leaching loss, $\mathrm{N}_{1}$ $=\mathrm{N}$ loss through gas $\left(\mathrm{NO}, \mathrm{N}_{2} \mathrm{O}\right.$, and nitrogen dioxide $\left[\mathrm{NO}_{2}\right]$ ) emissions, and $\mathrm{N}_{\mathrm{m}}=$ $\mathrm{N}$ loss through surface runoff. Nitrogen loss through $\mathrm{NH}_{3}$ volatilization $\left(\mathrm{N}_{\mathrm{h}}\right)$ was estimated as $15 \%$ of applied $\mathrm{N}$ (Meisinger and Randall 1991; Migliorati et al. 2014). Denitrification $\mathrm{N}$ loss $\left(\mathrm{N}_{\mathrm{i}}\right)$ was estimated as $13 \%$ of total $\mathrm{N}$ input from $\mathrm{N}$ fertilizer and atmospheric $\mathrm{N}$ deposition after deducting $\mathrm{N}$ loss through $\mathrm{NH}_{3}$ volatilization (Meisinger and Randall 1991; Sainju 2017). Denitrification loss of biologically fixed $\mathrm{N}$ was considered negligible in the calculation of this parameter (Meisinger and Randall 1991). Nitrogen loss through plant senescence $\left(\mathrm{N}_{\mathrm{j}}\right)$ was estimated as $5 \%$ of total aboveground biomass $\mathrm{N}$ (Meisinger and Randall 1991; Sainju 2017). Nitrogen leaching loss $\left(\mathrm{N}_{\mathrm{k}}\right)$ for the semiarid region was estimated as $9 \mathrm{~kg} \mathrm{~N} \mathrm{ha}^{-1} \mathrm{y}^{-1}$ for malt barley and $12 \mathrm{~kg} \mathrm{~N} \mathrm{ha}^{-1} \mathrm{y}^{-1}$ for pea (Delgado et al. 2008; Ross et al. 2008). Gaseous N loss ( $\mathrm{NO}, \mathrm{N}_{2} \mathrm{O}$, and $\mathrm{NO}_{2}$ emissions; $\mathrm{N}_{1}$ ) was estimated as $1.5 \%$ of the applied $\mathrm{N}$ fertilizer (IPCC 2014). Nitrogen loss through surface runoff $\left(\mathrm{N}_{\mathrm{m}}\right)$ was estimated as $1 \%$ of the applied $\mathrm{N}$ fertilizer (Legg and Meisinger 1982; Ross et al. 2008). The estimated values were obtained from literatures based on similar soil and climatic conditions and cropping systems as our experimental site (e.g., medium textured soil [loam and silt loam], precipitation $<500 \mathrm{~mm}$, and management practices [till versus no-till practices and crop rotation versus monocropping]).

Nitrogen balance was calculated as

Nitrogen balance $=$ Total $\mathrm{N}$ input - Total $\mathrm{N}$ output $-\mathrm{N}$ sequestration rate.

Change in $\mathrm{N}$ level was calculated by deducting total $\mathrm{N}$ output from total $\mathrm{N}$ input. A positive value of $\mathrm{N}$ balance indicated $\mathrm{N}$ surplus and negative value as $\mathrm{N}$ deficit in the agroecosystem. This value was used to evaluate the agroecosystem performance and environmental sustainability due to $\mathrm{N}$ inputs, outputs, and retention in the soil. Because some parameters were estimated in the calculation of $\mathrm{N}$ balance, the uncertainty in $\mathrm{N}$ balance was shown as the standard deviation of the mean values.

Data Analysis. Data for annualized crop residue $\mathrm{N}$ and grain $\mathrm{N}$ removal, soil bulk density and total $\mathrm{N}$ content, $\mathrm{N}$ fertilization rate, total $\mathrm{N}$ input and output, change in $\mathrm{N}$ level, and $\mathrm{N}$ balance were analyzed using the MIXED procedure of SAS (Littell et al. 2006). Irrigation practice was considered as the main-plot factor and cropping system as the split-plot factor for data analysis. Fixed effects were irrigation practice, cropping system, and their interactions; random effects were replication and irrigation $\times$ replication; and repeated measure variable was year. Means were separated by using the least square means test when treatments and interactions were significant (Littell et al. 2006). For data analysis, values for crop and soil parameters in NTB-P were determined by averaging the values for malt barley and pea phases of the rotation. Linear regression was conducted between soil total $\mathrm{N}$ and year to determine $\mathrm{N}$ sequestration rate from the slope of the line. Because the coefficient of determination $\left(R^{2}\right)$ for the regression equation was not significant for all treatments, $N$ sequestration rate was calculated by deducting soil total $\mathrm{N}$ in 2011 from that in 2006 and divided by the number of years (six). Statistical significance was evaluated at $p \leq$ 0.05 , unless otherwise stated.

\section{Results and Discussion}

Crop Residue Nitrogen. Differences in biomass production and $\mathrm{N}$ uptake resulted in 
variations in crop residue $\mathrm{N}$ returned to the soil among cropping systems and years, with significant interactions for irrigation practice $\times$ cropping system and cropping system $\times$ year (table 1 ). Averaged across irrigation practices, residue $\mathrm{N}$ was greater with CTBN, NTB-P, and NTBN than CTBO and NTBO in all years, except in 2010 when residue $\mathrm{N}$ was greater with $\mathrm{CTBN}$, NTB-P, and NTBN than NTBO (table 2). Similarly, residue $\mathrm{N}$ was greater with $\mathrm{CTBN}$, NTB$\mathrm{P}$, and NTB-N than CTBO and NTBO in both irrigated and nonirrigated practices when averaged across years. Residue $\mathrm{N}$ was greater in the irrigated than the nonirrigated practice with NTB-P and NTBN, but the trend reversed with CTBO. Residue N, averaged across treatments, was lower in 2011 than other years.

Increased $\mathrm{N}$ availability with $\mathrm{N}$ fertilization and biological $\mathrm{N}$ fixed by pea increased crop residue $\mathrm{N}$ with CTBN, NTB-P, and NTBN in most years. This was also true in both irrigated and nonirrigated practices. Increased crop $\mathrm{N}$ uptake with $\mathrm{N}$ fertilization than without, regardless of irrigation practices, has been reported by several researchers (Halvorson and Reule 2007; Abeledo et al. 2008). Similarly, increased crop residue N with barley-pea rotation compared with continuous barley at $0 \mathrm{~kg} \mathrm{~N} \mathrm{ha}^{-1}$ due to $\mathrm{N}$ fixation by pea has been reported elsewhere (Sainju 2013). Nondifference in residue $N$ between CTBN and NTBN or between $\mathrm{CTBO}$ and NTBO suggests that tillage had no effect on crop residue $\mathrm{N}$ returned to the soil. Similar results have been reported by some researchers in dryland cropping systems (Halvorson et al. 2002; Sainju et al. 2012). Increased water availability from irrigation compared to nonirrigation increased residue $\mathrm{N}$ only with NTB-P and NTBN, suggesting that irrigation favors crop $\mathrm{N}$ uptake in the presence of enough $\mathrm{N}$ supply under no-till condition. Increased $\mathrm{N}$ leaching in coarse-textured soil may have reduced soil $\mathrm{N}$ availability and therefore crop residue $\mathrm{N}$ uptake in 2011 when the growing season (April to August) and total annual precipitation was greater than other years (figure 1). Differences in crop residue $\mathrm{N}$ input among treatments is expected to influence soil total $\mathrm{N}$, as discussed below.

Nitrogen Inputs. The amount of $\mathrm{N}$ fertilizer applied to malt barley varied with irrigation practices, cropping systems, and years, with significant interactions for irriga-

\section{Table 1}

Analysis of variance for crop nitrogen $(\mathrm{N})$ removal, soil total $\mathrm{N}, \mathrm{N}$ inputs and outputs, change in $\mathrm{N}$ level, and $\mathrm{N}$ balance with sources of variance from irrigation practice (IR), cropping system (CS), year $(Y)$, and their interactions.

\begin{tabular}{|c|c|c|c|c|c|c|c|c|c|}
\hline Source & $\begin{array}{l}\text { Grain } \mathbf{N} \\
\text { removal }\end{array}$ & $\begin{array}{l}\text { Crop } \\
\text { residue } \\
\mathbf{N}\end{array}$ & $\begin{array}{l}\text { Amount } \\
\text { of } N \\
\text { fertilizer } \\
\text { applied }\end{array}$ & $\begin{array}{l}\text { Soil } \\
\text { total N }\end{array}$ & $\begin{array}{l}\text { Irrigation } \\
\mathrm{N} \text { input }\end{array}$ & $\begin{array}{l}\text { Total N } \\
\text { input }\end{array}$ & $\begin{array}{l}\text { Total N } \\
\text { output }\end{array}$ & $\begin{array}{l}\text { Change } \\
\text { in } \mathrm{N} \text { level }\end{array}$ & $\begin{array}{l}\mathrm{N} \\
\text { balance }\end{array}$ \\
\hline IR & NS & NS & * & NS & * & $* *$ & * & $* *$ & $* *$ \\
\hline CS & $\star * *$ & $* * *$ & $* * *$ & NS & NS & $* *$ & $* * *$ & NS & $* * *$ \\
\hline $\mathrm{IR} \times \mathrm{CS}$ & $* * *$ & $* *$ & $* * *$ & * & NS & $* *$ & $* * *$ & $*$ & $* *$ \\
\hline Y & $* * *$ & $* \star *$ & ** & $* * *$ & $* * *$ & $* * *$ & $* * *$ & $* * *$ & $* * *$ \\
\hline$I R \times Y$ & $*$ & NS & NS & NS & $* * *$ & ** & ** & NS & NS \\
\hline$C S \times Y$ & $* * *$ & * & * & NS & NS & * & ** & $* *$ & ** \\
\hline $\begin{array}{c}\mathrm{IR} \times \mathrm{CS} \\
\times \mathrm{Y}\end{array}$ & NS & NS & NS & NS & NS & NS & NS & NS & NS \\
\hline
\end{tabular}

\section{Table 2}

Crop residue nitrogen ( $\mathrm{N}$; $\mathrm{kg} \mathrm{N} \mathrm{ha}^{-1}$ ) returned to the soil from 2006 to 2011 as affected by cropping system and interaction between irrigation practice and cropping system.

\begin{tabular}{lllllllllll}
\hline & \multicolumn{1}{l}{ Year } \\
\cline { 2 - 5 } $\begin{array}{l}\text { Cropping } \\
\text { system }\end{array}$ & $\mathbf{2 0 0 6}$ & $\mathbf{2 0 0 7}$ & $\mathbf{2 0 0 8}$ & $\mathbf{2 0 0 9}$ & $\mathbf{2 0 1 0}$ & $\mathbf{2 0 1 1}$ & Mean & Irrigated & Nonirrigated \\
\hline CTBN & $44 \mathrm{a} *$ & $56 \mathrm{a}$ & $56 \mathrm{a}$ & $68 \mathrm{a}$ & $31 \mathrm{a}$ & $28 \mathrm{a}$ & $47 \mathrm{a}$ & $49 \mathrm{a}$ & $46 \mathrm{a}$ \\
CTBO & $34 \mathrm{~b}$ & $32 \mathrm{~b}$ & $28 \mathrm{~b}$ & $25 \mathrm{~b}$ & $21 \mathrm{ab}$ & $10 \mathrm{~b}$ & $25 \mathrm{~b}$ & $21 \mathrm{bB}$ & $29 \mathrm{bA} \dagger$ \\
NTB-P & $46 \mathrm{a}$ & $54 \mathrm{a}$ & $61 \mathrm{a}$ & $69 \mathrm{a}$ & $40 \mathrm{a}$ & $34 \mathrm{a}$ & $51 \mathrm{a}$ & $55 \mathrm{aA}$ & $46 \mathrm{aB}$ \\
NTBN & $45 \mathrm{a}$ & $58 \mathrm{a}$ & $57 \mathrm{a}$ & $63 \mathrm{a}$ & $28 \mathrm{a}$ & $26 \mathrm{a}$ & $46 \mathrm{a}$ & $49 \mathrm{aA}$ & $43 \mathrm{aB}$ \\
NTBO & $26 \mathrm{~b}$ & $23 \mathrm{~b}$ & $27 \mathrm{~b}$ & $24 \mathrm{~b}$ & $11 \mathrm{~b}$ & $11 \mathrm{~b}$ & $20 \mathrm{~b}$ & $18 \mathrm{~b}$ & $22 \mathrm{~b}$ \\
\hline
\end{tabular}

Notes: CTBN $=$ conventional till malt barley with 67 to $134 \mathrm{~kg} \mathrm{~N} \mathrm{ha}^{-1}$. CTBO $=$ conventional till malt barley with $0 \mathrm{~kg} \mathrm{~N} \mathrm{ha}^{-1}$. NTB-P = no-till malt barley-pea with 67 to $134 \mathrm{~kg} \mathrm{~N} \mathrm{ha}^{-1}$. NTBN = no-till malt barley with 67 to $134 \mathrm{~kg} \mathrm{~N} \mathrm{ha}^{-1}$. NTBO $=$ no-till malt barley with $0 \mathrm{~kg} \mathrm{~N} \mathrm{ha}^{-1}$.

* Numbers followed by different lowercase letters within a column are significantly different at $p$ $=0.05$ by the least significant difference test.

$\dagger$ Numbers followed by different uppercase letters within a row are significantly different at $p=$ 0.05 by the least significant difference test.

tion practice $\times$ cropping system and cropping system $\times$ year (table 1 ). The amount of $N$ fertilizer, averaged across irrigation practices, was greater with CTBN and NTBN than other cropping systems and greater with NTB-P than CTBO and NTBO in all years (table 3). Because of $\mathrm{N}$ supplied by pea residue as a result of $\mathrm{N}$ fixation, the amount of N fertilizer was lower with NTB-P than CTBN and NTBN. Presence of increasing level of soil residual $\mathrm{N}$ reduced the amount of $\mathrm{N}$ fertilizer applied from 2006 to 2011 with CTBN, NTBN, and NTB-P.

Averaged across cropping systems, the amount of $\mathrm{N}$ fertilizer was greater with the irrigated than the nonirrigated practice because irrigated malt barley used more $\mathrm{N}$ and increased yield compared with nonirrigated malt barley (table 4). The amount of $\mathrm{N}$ fertilizer applied to malt barley with NTB-P was less than half of that applied with CTBN and NTBN, regardless of irrigation practices, due to $\mathrm{N}$ contribution from pea residue.

Biological $N$ fixed by pea with NTB-P was greater with the irrigated than the nonirrigated practice in 2006, 2008, 2009, and 2010 (table 5). Enhanced pea yield due to increased water availability increased biological $\mathrm{N}$ fixation with the irrigated practice in these years. Biological $N$ fixed by pea averaged $78 \mathrm{~kg} \mathrm{~N} \mathrm{ha}^{-1} \mathrm{y}^{-1}$ in the irrigated 
Figure 1

Growing season (April to August) and total annual precipitation from 2006 to 2011 at the experimental site.

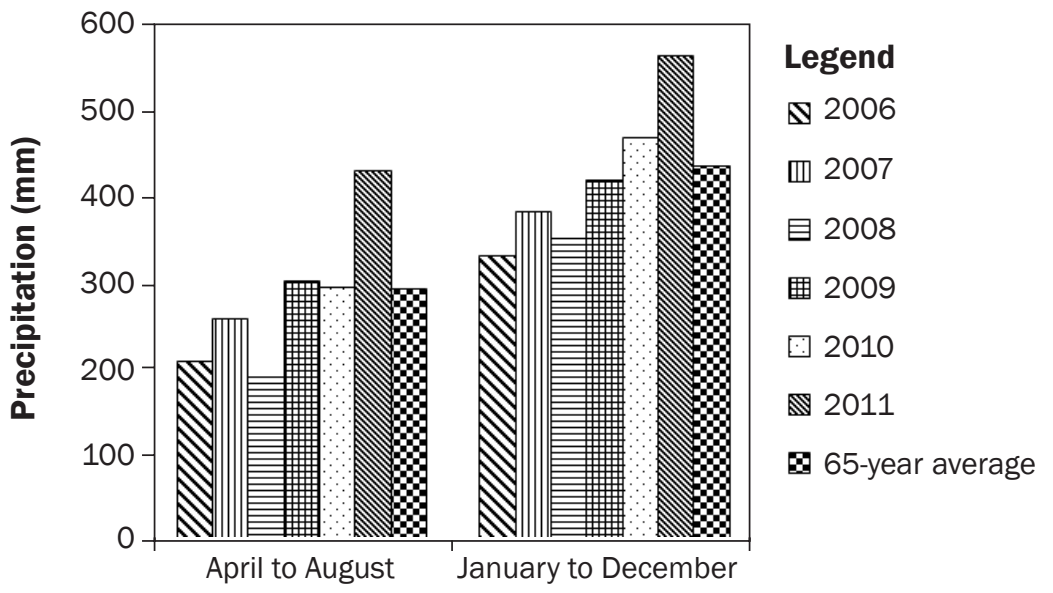

practice and $57 \mathrm{~kg} \mathrm{~N} \mathrm{ha}^{-1} \mathrm{y}^{-1}$ in the nonirrigated practice (tables 4 and 5).

Nitrogen added from irrigation water varied with irrigation practices and years, with a significant irrigation practice $\times$ year interaction (table 1). Irrigation $N$ input varied from $9 \mathrm{~kg} \mathrm{~N} \mathrm{ha}{ }^{-1}$ in 2008 to $47 \mathrm{~kg} \mathrm{~N} \mathrm{ha}{ }^{-1}$ in 2006, with an average of $21 \mathrm{~kg} \mathrm{~N} \mathrm{ha}^{-1} \mathrm{y}^{-1}$ in the irrigated cropping system (tables 4 and 5). Nitrogen input varied among years due to difference in the amount of water applied through irrigation, which depended on soil water content and crop demand. When the growing season precipitation was lower, $\mathrm{N}$ input from irrigation water increased due to increased amount of water applied to sustain crop yields.

\section{Table 3}

Amount of nitrogen ( $\mathrm{N}$; $\mathrm{kg} \mathrm{N} \mathrm{ha}^{-1}$ ) fertilizer applied to barley from 2006 to 2011 as affected by cropping system.

\begin{tabular}{llllllll}
\hline $\begin{array}{l}\text { Cropping } \\
\text { system }\end{array}$ & $\mathbf{2 0 0 6}$ & $\mathbf{2 0 0 7}$ & $\mathbf{2 0 0 8}$ & $\mathbf{2 0 0 9}$ & $\mathbf{2 0 1 0}$ & $\mathbf{2 0 1 1}$ & Mean \\
\hline CTBN & $90 \mathrm{a} *$ & $75 a$ & $60 \mathrm{a}$ & $58 \mathrm{a}$ & $60 \mathrm{a}$ & $60 \mathrm{a}$ & $67 \mathrm{a}$ \\
CTBO & Oc & Oc & Oc & Oc & Oc & Oc & Oc \\
NTB-P & 45b & $38 \mathrm{~b}$ & $25 \mathrm{~b}$ & $33 \mathrm{~b}$ & $23 \mathrm{~b}$ & $23 \mathrm{~b}$ & $29 \mathrm{~b}$ \\
NTBN & 90a & $75 \mathrm{a}$ & 60a & $58 \mathrm{a}$ & $60 \mathrm{a}$ & $60 \mathrm{a}$ & $67 \mathrm{a}$ \\
NTBO & Oc & Oc & Oc & Oc & Oc & Oc & Oc \\
\hline
\end{tabular}

Notes: CTBN = conventional till malt barley with 67 to $134 \mathrm{~kg} \mathrm{~N} \mathrm{ha}^{-1}$. CTBO $=$ conventional till malt barley with $0 \mathrm{~kg} \mathrm{~N} a^{-1}$. NTB-P = no-till malt barley-pea with 67 to $134 \mathrm{~kg} \mathrm{~N}^{-1}$. NTBN = no-till malt barley with 67 to $134 \mathrm{~kg} \mathrm{~N} \mathrm{ha}^{-1}$. NTBO $=$ no-till malt barley with $0 \mathrm{~kg} \mathrm{~N} \mathrm{ha}^{-1}$.

*Numbers followed by different letters within a column in a set are significantly different at $p=$ 0.05 by the least significant difference test.
Total $\mathrm{N}$ input varied with irrigation practices, cropping systems, and years, with significant interactions for irrigation practice $\times$ cropping system, irrigation practice $\times$ year, and cropping system $\times$ year (table 1 ). Total $\mathrm{N}$ input, averaged across years, was greater with NTB-P than other cropping systems in both irrigated and nonirrigated practices (table 4). Nitrogen added from $\mathrm{N}$ fertilizer, together with pea $\mathrm{N}$ fixation, and increased $\mathrm{N}$ from crop seeds increased total $\mathrm{N}$ input with NTB-P. Total N input, averaged across cropping systems, was greater with the irrigated than the nonirrigated practice because $\mathrm{N}$ rate to malt barley, irrigation $\mathrm{N}$ input, and soil $\mathrm{N}$ mineralization were greater for the irrigated than the nonirrigated condition.

Nitrogen Outputs. Crop grain $\mathrm{N}$ removal varied among cropping systems and years, with significant interactions for irrigation practice $\times$ cropping system, irrigation practice $\times$ year, and cropping system $\times$ year (table 1). Grain $N$ removal, averaged across cropping systems, was greater with the irrigated than the nonirrigated practice in 2006 and 2008 (table 6) when the growing season precipitation was lower than other years (figure 1). Additional $\mathrm{N}$ input through increased amount of water applied from irrigation appeared to increase grain $\mathrm{N}$ removal during these years. Grain N removal, however, was not affected by irrigation practice during years with near or above-average precipitation, suggesting that malt barley and pea grains were not able to remove $\mathrm{N}$ during years with adequate precipitation, even though $\mathrm{N}$ rate was higher for irrigated than nonirrigated crops.

Grain $\mathrm{N}$ removal, averaged across irrigation practices, was greater with CTBN and NTBN than other cropping systems in 2006 and greater with CTBN, NTB-P, and NTB-N than CTBO and NTBO from 2007 to 2010 (table 6). Nitrogen applied from $\mathrm{N}$ fertilizer and/or $\mathrm{N}$ fixed by pea increased grain $\mathrm{N}$ removal with CTBN, NTBN, and NTB-P. Lower yield of pea reduced grain $N$ removal with NTB-P compared with CTBN and NTBN in 2006. Grain N removal, averaged across years, was also greater with CTBN, NTB-P, and CTBN than CTBO and NTBO in irrigated and nonirrigated practices (table 4) due to $\mathrm{N}$ applied from fertilizer and/or $\mathrm{N}$ fixed by pea. Nondifference in grain $\mathrm{N}$ removal between CTBN and NTBN or between CTBO and NTBO suggest that tillage had no effect on grain 
Table 4

Nitrogen $(\mathrm{N})$ balance $\left(\mathrm{kg} \mathrm{N} \mathrm{ha}^{-1} \mathrm{y}^{-1}\right)$ based on $\mathrm{N}$ inputs, outputs, and soil $\mathrm{N}$ retention as affected by irrigation practice and cropping system.

\begin{tabular}{|c|c|c|c|c|c|c|c|c|c|c|}
\hline \multirow[b]{2}{*}{ Parameter } & \multicolumn{5}{|c|}{ Irrigated practice } & \multicolumn{5}{|c|}{ Nonirrigated practice } \\
\hline & CTBN & СТВо & NTB-P & NTBN & NTBO & CTBN & СТВO & NTB-P & NTBN & NTBO \\
\hline \multicolumn{11}{|l|}{$\mathrm{N}$ inputs } \\
\hline $\mathrm{N}$ fertilization rate & $89 a *$ & Od & $40 \mathrm{~b}$ & $89 a$ & Od & $45 b$ & 0 & $18 \mathrm{c}$ & $45 b$ & Od \\
\hline Pea $\mathrm{N}$ fixation & Oc & Oc & $78 a$ & Oc & Oc & Oc & Oc & $57 b$ & Oc & Oc \\
\hline Irrigation N & $21 a$ & $21 a$ & $21 a$ & $21 a$ & $21 a$ & $\mathrm{Ob}$ & $\mathrm{Ob}$ & $\mathrm{Ob}$ & $\mathrm{Ob}$ & $\mathrm{Ob}$ \\
\hline Soil N mineralization & 32 & 28 & 31 & 31 & 30 & 16 & 16 & 16 & 15 & 16 \\
\hline Atmospheric $\mathrm{N}$ deposition & 14 & 14 & 14 & 14 & 14 & 14 & 14 & 14 & 14 & 14 \\
\hline $\mathrm{N}$ added by crop seed & $2 b$ & $2 b$ & $7 a$ & $2 b$ & $2 b$ & $2 b$ & $2 b$ & $7 a$ & $2 b$ & $2 b$ \\
\hline Nonsymbiotic $\mathrm{N}$ fixation & 5 & 5 & 5 & 5 & 5 & 5 & 5 & 5 & 5 & 5 \\
\hline Total N input & $163 b$ & $70 d$ & $196 a$ & $162 b$ & $72 d$ & $82 d$ & $37 e$ & $117 \mathrm{c}$ & $81 d$ & $37 e$ \\
\hline \multicolumn{11}{|l|}{ N outputs } \\
\hline Grain N removal & $87 a b$ & $42 c$ & $91 \mathrm{a}$ & $84 a b$ & $34 c$ & $72 b$ & $46 c$ & $70 b$ & $75 b$ & $43 c$ \\
\hline Ammonia volatilization & 13 & 0 & 6 & 13 & 0 & 7 & 0 & 3 & 7 & 0 \\
\hline Denitrification & 14 & 5 & 9 & 14 & 5 & 7 & 2 & 4 & 7 & 2 \\
\hline Plant senescence & 7 & 3 & 7 & 7 & 3 & 6 & 4 & 6 & 6 & 3 \\
\hline N leaching & 12 & 1 & 14 & 14 & 1 & 7 & 1 & 8 & 8 & 1 \\
\hline Gaseous $\mathrm{N}\left(\mathrm{NO}_{\mathrm{x}}\right)$ emissions & 1 & 0 & 1 & 1 & 0 & 1 & 0 & 0 & 1 & 0 \\
\hline Surface runoff & 1 & 0 & 0 & 1 & 0 & 0 & 0 & 0 & 0 & 0 \\
\hline Total N output & $136 a$ & $51 c$ & $128 a$ & $135 a$ & $43 c$ & $100 b$ & $53 c$ & $91 b$ & $104 b$ & $49 c$ \\
\hline Change in $\mathrm{N}$ level† & $27 b$ & $19 b$ & $68 a$ & $27 b$ & $29 b$ & $-18 c$ & $-16 c$ & $26 b$ & $-23 c$ & $-12 c$ \\
\hline $\mathrm{N}$ sequestration rate $\neq$ & 13 & 6 & 34 & 37 & 19 & 10 & 34 & 37 & 31 & 29 \\
\hline $\mathrm{N}$ balance $\S$ & $14( \pm 6) b$ & $13( \pm 5) b$ & $34( \pm 8) a$ & $-10( \pm 3) c$ & $10( \pm 4) b$ & $-28( \pm 6) d$ & $-50( \pm 8) e$ & $-11( \pm 3) c$ & $-54( \pm 10) e$ & $-41( \pm 8) \mathrm{e}$ \\
\hline
\end{tabular}

Notes: CTBN = conventional till malt barley with 67 to $134 \mathrm{~kg} \mathrm{~N} \mathrm{ha}^{-1}$. CTBO $=$ conventional till malt barley with $0 \mathrm{~kg} \mathrm{~N} \mathrm{ha}^{-1}$. NTB-P $=$ no-till malt barley-pea with 67 to $134 \mathrm{~kg} \mathrm{~N} \mathrm{ha}^{-1}$. NTBN = no-till malt barley with 67 to $134 \mathrm{~kg} \mathrm{~N} \mathrm{ha}^{-1}$. NTBO = no-till malt barley with $0 \mathrm{~kg} \mathrm{~N}^{-1}$.

* Numbers followed by different letters in a row are significantly different at $p \leq 0.05$ by the least square means test.

†Change in $\mathrm{N}$ level $=$ total $\mathrm{N}$ input - total $\mathrm{N}$ output.

$\ddagger$ Calculated as rate of change in soil total $\mathrm{N}$ content from 2007 to 2011.

$\S \mathrm{N}$ balance $=$ change in $\mathrm{N}$ level $-\mathrm{N}$ sequestration rate $(0$ to $10 \mathrm{~cm})$. Values are mean $( \pm$ standard deviation $)$.

$\mathrm{N}$ removal. Such results were also reported by various researchers in the northern Great Plains (Halvorson et al. 2002; Lenssen et al. 2007; Sainju et al. 2012).

Estimated $\mathrm{N}$ losses through $\mathrm{NH}_{3}$ volatilization and denitrification were greater with CTBN and NTBN than other cropping systems in both irrigated and nonirrigated practices (table 4) because of $\mathrm{N}$ fertilization to malt barley in these systems. Lower $\mathrm{N}$ rate as a result of $\mathrm{N}$ fixation by pea reduced $\mathrm{N}$ losses through $\mathrm{NH}_{3}$ volatilization and denitrification with NTB-P. Similarly, lower $\mathrm{N}$ rate to malt barley reduced $\mathrm{N}$ losses through $\mathrm{NH}_{3}$ volatilization and denitrification in the nonirrigated than the irrigated practice. Nitrogen losses through $\mathrm{NH}_{3}$ volatilization and denitrification increase with increased $\mathrm{N}$ fertilization rate (Meisinger and Randall 1991; Ross et al. 2008; Pieri et al. 2011). Absence of $\mathrm{N}$ fertilization resulted in no $\mathrm{N}$ loss through $\mathrm{NH}_{3}$ volatilization with $\mathrm{CTBO}$ and NTBO; however, denitrification of $\mathrm{N}$ inputs through atmospheric deposition, soil $\mathrm{N}$ mineralization, and irrigation water resulted in some $\mathrm{N}$ loss through this process with CTBO and NTBO.

Nitrogen loss through plant senescence depended on total aboveground biomass $\mathrm{N}$ (Meisinger and Randall 1991; Ross et al 2008). Because of greater crop residue $N$ and grain $\mathrm{N}$ removal, estimated $\mathrm{N}$ loss through plant senescence was greater with CTBN, NTBN, and NTB-P than other cropping systems (table 4). Estimated $\mathrm{N}$ leaching loss was greater with CTBN, NTBN, and NTB-P than other cropping systems due to $\mathrm{N}$ fertilization and/or $\mathrm{N}$ fixed by pea. Nitrogen leaching increases as $\mathrm{N}$ inputs from fertilizer and legume $\mathrm{N}$ fixation increase (Ross et al 2008; Pieri et al. 2011; IPCC 2014; Migliorati et al. 2014). Similarly, estimated N leaching loss was greater for the irrigated than the nonirrigated practice due to increased $\mathrm{N}$ rate to malt barley in the irrigated condition. Estimated $\mathrm{N}$ losses through gaseous $\mathrm{N}$ (NO,
$\mathrm{N}_{2} \mathrm{O}$, and $\mathrm{NO}_{2}$ ) emissions and surface runoff were minor for all treatments.

Total $\mathrm{N}$ output also varied with irrigation practices, cropping systems, and years, with significant interactions for irrigation practice $\times$ cropping system, irrigation practice $\times$ year, and cropping system $\times$ year, similar to total $N$ input (table 1). Total $\mathrm{N}$ output, averaged across years, was greater with CTBN, NTBN, and NTB-P than other cropping systems in both irrigated and nonirrigated practices (table 4). Greater grain $N$ removal and $N$ losses through $\mathrm{NH}_{3}$ volatilization, denitrification, plant senescence, and leaching increased total $\mathrm{N}$ output in these cropping systems. Similarly, increased $\mathrm{N}$ losses through $\mathrm{NH}_{3}$ volatilization, denitrification, plant senescence, and leaching increased total $\mathrm{N}$ output in the irrigated than the nonirrigated practice.

Soil Total Nitrogen. Soil total $\mathrm{N}$ at the 0 to $10 \mathrm{~cm}$ depth varied with years, with a significant irrigation practice $\times$ cropping system interaction (table 1). Soil total 


\section{Table 5}

Pea nitrogen ( $\mathrm{N}$ ) fixation in no-till barley-pea rotation with $\mathrm{N}$ fertilization (NTB-P; $\mathrm{kg} \mathrm{N} \mathrm{ha}^{-1}$ ) as affected by irrigation practice and amount of $\mathrm{N}$ applied in irrigation water.

\begin{tabular}{|c|c|c|c|c|c|c|c|}
\hline Irrigation & 2006 & 2007 & 2008 & 2009 & 2010 & 2011 & Mean \\
\hline \multicolumn{8}{|l|}{ Pea $N$ fixation } \\
\hline Irrigated & $70 a *$ & 76 & $86 a$ & $101 a$ & $78 a$ & 58 & $78 a$ \\
\hline Nonirrigated & $44 b$ & 63 & $63 b$ & $77 b$ & $38 b$ & 57 & $57 b$ \\
\hline \multicolumn{8}{|l|}{$\begin{array}{l}\mathrm{N} \text { applied in } \\
\text { irrigation water }\end{array}$} \\
\hline Irrigated & $47 a$ & $11 a$ & $9 a$ & $26 a$ & $18 a$ & $14 a$ & $21 a$ \\
\hline Nonirrigated & $\mathrm{Ob}$ & $\mathrm{Ob}$ & $\mathrm{Ob}$ & $\mathrm{Ob}$ & $\mathrm{Ob}$ & $\mathrm{Ob}$ & $\mathrm{Ob}$ \\
\hline
\end{tabular}

* Numbers followed by different letters within a column in a set are significantly different at $p=$ 0.05 by the least significant difference test.

$\mathrm{N}$, averaged across years, was greater with CTBN than CTBO and NTBO and greater with NTB-P and NTBN than CTBO in the irrigated practice (table 7). In the irrigated practice, soil total $\mathrm{N}$ was greater with $\mathrm{CTBO}$ than NTBN. Soil total N was greater in the irrigated than nonirrigated practice with CTBO and NTBO.

Increased crop residue $\mathrm{N}$ returned to the soil due to $\mathrm{N}$ fertilization (table 2), followed by incorporation of crop residue likely increased soil total $\mathrm{N}$ with CTBN in the irrigated practice. While increased $\mathrm{N}$ input can increase soil total N (Gregorich et al. 1996; Omay et al. 1997), rapid turnover of crop residue $\mathrm{N}$ to soil organic $\mathrm{N}$ due to tillage and irrigation can increase soil total $\mathrm{N}$ under irrigated and tilled crops (Clapp et al. 2000). When $\mathrm{N}$ fertilizer was not applied, reduced crop residue $\mathrm{N}$ input and tillage, however, reduced soil total $\mathrm{N}$ with $\mathrm{CTBO}$ in the irrigated practice. In contrast, in the absence of irrigation, soil total $\mathrm{N}$ increased in nonirrigated CTBO, possibly because limited water availability reduced soil microbial activity and mineralization of soil organic N. This also holds true for greater soil total $\mathrm{N}$ in the nonirrigated than the irrigated practice with $\mathrm{CTBO}$ and NTBO. Absence of $\mathrm{N}$ fertilization may have increased $\mathrm{C} / \mathrm{N}$ ratio of the soil, resulting in reduced soil $\mathrm{N}$ mineralization and therefore increased soil total $\mathrm{N}$ with $\mathrm{CTBO}$ and NTBO in the nonirrigated condition.

Nitrogen sequestration rate was greater with NTB-P and NTBN than CTBN, $\mathrm{CTBO}$, and $\mathrm{NTBO}$ in the irrigated practice, but lower with CTBN than other cropping systems in the nonirrigated practice (table 4). Increased crop residue $\mathrm{N}$ input, followed by reduced soil disturbance as a result of no-till likely increased $\mathrm{N}$ sequestration rates with NTB-P and NTB-N. Similar results have been reported by some researchers (Jastrow et al. 1996; Omay et al. 1997; Sainju 2013).
Nitrogen sequestration rate, however, was not different between irrigated and nonirrigated practices because crop residue $\mathrm{N}$ returned to the soil was not affected by irrigation practice (table 2).

Nitrogen Balance. Change in $\mathrm{N}$ level, as the difference between total $\mathrm{N}$ input and output, varied with irrigation practice and years, with significant interactions for irrigation practice $\times$ cropping system and cropping system $\times$ year (table 1 ). Change in $\mathrm{N}$ level, averaged across years, was greater with NTB-P than other cropping systems in both irrigated and nonirrigated practices (table 4). Increased total $\mathrm{N}$ input compared to total $\mathrm{N}$ output increased change in $\mathrm{N}$ level with NTB-P, regardless of irrigation practices. Similarly, increased total $\mathrm{N}$ input compared to total $\mathrm{N}$ output increased change in $\mathrm{N}$ level with the irrigated than the nonirrigated practice when averaged across cropping systems and years.

\section{Table 6}

Crop grain nitrogen $(\mathrm{N})$ removal $\left(\mathrm{kg} \mathrm{N} \mathrm{ha}^{-1}\right)$ from 2006 to 2011 as affected by irrigation practice and cropping system.

\begin{tabular}{lllllllll}
\hline $\begin{array}{l}\text { Irrigation } \\
\text { practice }\end{array}$ & $\begin{array}{l}\text { Cropping } \\
\text { system }\end{array}$ & \multicolumn{6}{l}{ Grain N removal } \\
\cline { 3 - 10 } & $\mathbf{2 0 0 6}$ & $\mathbf{2 0 0 7}$ & $\mathbf{2 0 0 8}$ & $\mathbf{2 0 0 9}$ & $\mathbf{2 0 1 0}$ & $\mathbf{2 0 1 1}$ & Mean \\
\hline Irrigated & & $91 \mathrm{a} *$ & 78 & $74 \mathrm{a}$ & 58 & 61 & 39 & 68 \\
Nonirrigated & & $71 \mathrm{~b}$ & 88 & $62 \mathrm{~b}$ & 58 & 55 & 34 & 61 \\
& CTBN & $97 \mathrm{a}$ & $101 \mathrm{a}$ & $82 \mathrm{a}$ & $77 \mathrm{a}$ & $75 \mathrm{a}$ & $47 \mathrm{a}$ & $80 \mathrm{a}$ \\
& CTBO & $71 \mathrm{~b}$ & $52 \mathrm{~b}$ & $46 \mathrm{~b}$ & $27 \mathrm{~b}$ & $40 \mathrm{~b}$ & $16 \mathrm{~b}$ & $44 \mathrm{~b}$ \\
& NTB-P & $71 \mathrm{~b}$ & $101 \mathrm{a}$ & $83 \mathrm{a}$ & $87 \mathrm{a}$ & $87 \mathrm{a}$ & $59 \mathrm{a}$ & $81 \mathrm{a}$ \\
& NTBN & $102 \mathrm{a}$ & $102 \mathrm{a}$ & $90 \mathrm{a}$ & $71 \mathrm{a}$ & $70 \mathrm{a}$ & $42 \mathrm{a}$ & $80 \mathrm{a}$ \\
& NTBO & $64 \mathrm{~b}$ & $50 \mathrm{~b}$ & $40 \mathrm{~b}$ & $27 \mathrm{~b}$ & $33 \mathrm{~b}$ & $18 \mathrm{~b}$ & $39 \mathrm{~b}$ \\
\hline
\end{tabular}

Notes: CTBN $=$ conventional till malt barley with 67 to $134 \mathrm{~kg} \mathrm{~N} \mathrm{ha}^{-1}$. CTBO $=$ conventional till malt barley with $0 \mathrm{~kg} \mathrm{~N} \mathrm{ha}^{-1}$. NTB-P = no-till malt barley-pea with 67 to $134 \mathrm{~kg} \mathrm{~N}^{-1}{ }^{-1}$. NTBN = no-till malt barley with 67 to $134 \mathrm{~kg} \mathrm{~N} \mathrm{ha}^{-1}$. NTBO = no-till malt barley with $0 \mathrm{~kg} \mathrm{~N} \mathrm{ha-1.}$

*Numbers followed by different letters within a column in a set are significantly different at $p=$ 0.05 by the least significant difference test. 
balance have led to increased uncertainty. The uncertainty in estimated $\mathrm{N}$ inputs and outputs can range from $5 \%$ in atmospheric $\mathrm{N}$ deposition to as much as $50 \%$ in $\mathrm{N}$ losses through $\mathrm{NH}_{3}$ volatilization, denitrification, and $\mathrm{N}$ leaching (Meisinger and Randall 1991; Sainju 2017).

Greater $\mathrm{N}$ balance with CTBN than NTBN, but similar values between CTBO and NTBO in both irrigated and nonirrigated practices (table 4), suggests that tillage may increase $\mathrm{N}$ surplus compared to no-till by efficiently flowing $\mathrm{N}$ through the agroecosystem. This was in contrast to those reported by Sainju et al. (2016) who found that tillage increased $\mathrm{N}$ deficit compared to no-till under dryland cropping systems in eastern Montana. Differences in soil and climatic conditions and cropping systems may have resulted in variations in $\mathrm{N}$ balance among regions. Soil in my study was sandy loam compared with loam in eastern Montana. My study involved both irrigated and dryland cropping systems compared with a dryland cropping system in eastern Montana. Western North Dakota also receives $50 \mathrm{~mm}$ more annual precipitation than eastern Montana. In contrast, similar $\mathrm{N}$ balance between CTBN and CTBO or NTBN and NTBO suggests that N fertilization has little effect on $\mathrm{N}$ balance. Greater $\mathrm{N}$ surplus in the irrigated practice or lower $\mathrm{N}$ deficit in the nonirrigated practice with NTB-P than other cropping systems, however, suggests that legume-nonlegume rotation with reduced $\mathrm{N}$ rate can increase $\mathrm{N}$ surplus or reduce $\mathrm{N}$ deficit, a report similar to those documented by several researchers (Ross et al. 2008; Sainju et al. 2016). Our N balance values of -54 to $30 \mathrm{~kg} \mathrm{~N} \mathrm{ha}{ }^{-1} \mathrm{y}^{-1}$ were similar to or slightly greater than the reported values of -45 to $45 \mathrm{~kg} \mathrm{~N} \mathrm{ha}^{-1} \mathrm{y}^{-1}$ by several researchers (Korsaeth and Eltum 2000; Karlsson et al. 2003) who suggested that most of the $\mathrm{N}$ cycling under crop production occurred at the expense of soil total $\mathrm{N}$, which was highly variable among treatments and years.

The ratio of grain $\mathrm{N}$ removal to total $\mathrm{N}$ input was greater with CTBO than NTB-P and $\mathrm{NTBO}$ in the irrigated practice and greater with CTBO and NTBO than other cropping systems in the nonirrigated practice (table 8). The ratio was greater in the nonirrigated than the irrigated practice with CTBN, CTBO, and NTBO. This suggests that, out of total $\mathrm{N}$ input, greater $\mathrm{N}$

Table 7

Interaction between irrigation practice and cropping system on soil total nitrogen $(\mathrm{N})$ content at the 0 to $10 \mathrm{~cm}$ depth.

\begin{tabular}{lll}
\hline & \multicolumn{2}{l}{ Soil total $\mathbf{N}\left(\mathbf{M g} \mathbf{~ N ~} \mathbf{~ h}^{-\mathbf{1}}\right)$} \\
\cline { 2 - 3 } Cropping system & Irrigated practice & Nonirrigated practice \\
\hline CTBN & $1.60 \mathrm{a}^{*}$ & $1.57 \mathrm{ab}$ \\
CTBO & $1.42 \mathrm{cB} \dagger$ & $1.61 \mathrm{aA}$ \\
NTB-P & $1.54 \mathrm{ab}$ & $1.56 \mathrm{ab}$ \\
NTBN & $1.55 \mathrm{ab}$ & $1.51 \mathrm{~b}$ \\
NTBO & $1.50 \mathrm{bcB}$ & $1.59 \mathrm{abA}$ \\
\hline
\end{tabular}

Notes: CTBN $=$ conventional till malt barley with 67 to $134 \mathrm{~kg} \mathrm{~N} \mathrm{ha}^{-1}$. CTBO $=$ conventional till malt barley with $0 \mathrm{~kg} \mathrm{~N}^{-1}$. NTB-P = no-till malt barley-pea with 67 to $134 \mathrm{~kg} \mathrm{~N} \mathrm{ha}^{-1}$. NTBN = no-till malt barley with 67 to $134 \mathrm{~kg} \mathrm{~N} \mathrm{ha}^{-1}$. NTBO = no-till malt barley with $0 \mathrm{~kg} \mathrm{~N} \mathrm{ha}^{-1}$.

* Numbers followed by different lowercase letters within a column are significantly different at $p$ $=0.05$ by the least significant difference test.

$\dagger$ Numbers followed by different uppercase letters within a row are significantly different at $p=$ 0.05 by the least significant difference test.

was removed from the grain with $\mathrm{CTBO}$ in the irrigated practice and with $\mathrm{CTBO}$ and NTBO in the nonirrigated practice. Grain N removal was even higher than total $\mathrm{N}$ input with $\mathrm{N}$-unfertilized cropping systems in the nonirrigated practice. As $\mathrm{N}$ added through atmospheric $\mathrm{N}$ deposition, soil $\mathrm{N}$ mineralization, and nonsymbiotic $\mathrm{N}$ fixation were estimated from the literature, it is likely that more $\mathrm{N}$ could have added through these processes and $\mathrm{N}$-unfertilized crops could have more efficiently taken up $\mathrm{N}$ from the soil compared with $\mathrm{N}$-fertilized crops, especially under nonirrigated condition. Nitrogen-use efficiency of crops is reduced at higher $\mathrm{N}$ rates (Varvel and Peterson 1990). In contrast, the ratio of $\mathrm{N}$ loss to the environment to total $\mathrm{N}$ input was greater with CTBN and NTBN than other cropping systems in both irrigated and nonirrigated practices (table 8), suggesting that increased $\mathrm{N}$ fertilization rate to crops can increase $\mathrm{N}$ loss to the groundwater and the atmosphere, regardless of irrigation practices. Although grain $\mathrm{N}$ removal relative to total $\mathrm{N}$ input was lower, lower $\mathrm{N}$ loss to the environment with NTB-P compared with CTBN and NTBN suggests that legumenonlegume crop rotation with reduced $\mathrm{N}$ fertilization can reduce $\mathrm{N}$ loss compared with continuous nonlegumes applied with recommended $\mathrm{N}$ fertilizer. Similar results for lower $\mathrm{N}$ loss to the environment with legume-nonlegume rotation compared with continuous nonlegumes were reported by various researchers (Davis et al. 2003; Ross et al. 2008; Sainju et al. 2016). These results suggest that NTB-P can enhance the sustainability of agroecosystem by increasing $\mathrm{N}$ crop removal and reducing $\mathrm{N}$ loss to the environment and creating favorable $\mathrm{N}$ balance, regardless of irrigation practices - facts similar to our hypothesis.

\section{Summary and Conclusions}

Nitrogen balance in response to irrigation practices and cropping systems provided different pictures of $\mathrm{N}$ flows in the agroecosystem through $\mathrm{N}$ inputs, outputs, and retention in the soil. Irrigation practice resulted in $\mathrm{N}$ surplus compared with nonirrigated practice by increasing $\mathrm{N}$ inputs from $\mathrm{N}$ fertilization rate, pea $\mathrm{N}$ fixation, $\mathrm{N}$ added from irrigation water, and soil $\mathrm{N}$ mineralization while resulting in similar total $\mathrm{N}$ output through nonsignificant grain $\mathrm{N}$ removal. In contrast, nonirrigated practice resulted in $\mathrm{N}$ deficit due to increased total $\mathrm{N}$ output compared to total input. The CTBO and NTBO reduced total N inputs and outputs and resulted in slightly $\mathrm{N}$ surplus in the irrigated practice to major $\mathrm{N}$ deficit in the nonirrigated practice compared to other cropping systems. The NTB-P had greater N surplus in the irrigated practice and lower $\mathrm{N}$ deficit in the nonirrigated practice compared to other cropping systems. Nitrogen fertilization rate and $\mathrm{N}$ loss to the environment relative to total $\mathrm{N}$ input were also lower, but similar grain N removal with NTB-P compared to CTBN and NTBN. Because of similar grain $\mathrm{N}$ removal and favorable $\mathrm{N}$ balance, but reduced $\mathrm{N}$ loss to the environment, NTB-P can sustain agroecosystem performance and reduce environmental degradation compared to CTBN and NTBN, regardless of irrigation practices. These results matched to our hypothesis. 


\section{Table 8}

Ratio of crop grain nitrogen $(\mathrm{N})$ removal and $\mathrm{N}$ loss to the environment to total $\mathrm{N}$ input as affected by irrigation practice and cropping system.

\begin{tabular}{|c|c|c|c|c|}
\hline \multirow[b]{2}{*}{$\begin{array}{l}\text { Cropping } \\
\text { system }\end{array}$} & \multicolumn{2}{|c|}{ Grain $\mathrm{N}$ removal/total $\mathrm{N}$ input (\%) } & \multicolumn{2}{|c|}{$\mathrm{N}$ loss to the environment/total $\mathrm{N}$ input (\%) } \\
\hline & $\begin{array}{l}\text { Irrigated } \\
\text { practice }\end{array}$ & $\begin{array}{l}\text { Nonirrigated } \\
\text { practice }\end{array}$ & $\begin{array}{l}\text { Irrigated } \\
\text { practice }\end{array}$ & $\begin{array}{l}\text { Nonirrigated } \\
\text { practice }\end{array}$ \\
\hline CTBN & $53 a b B * \dagger$ & $88 \mathrm{bA}$ & $30 a$ & $34 a$ \\
\hline СТВО & $60 \mathrm{aB}$ & $124 a A$ & $13 b$ & $19 b$ \\
\hline NTB-P & $46 b$ & $60 c$ & $19 b$ & $18 b$ \\
\hline NTBN & $52 a b B$ & $93 \mathrm{bA}$ & $31 a$ & $36 a$ \\
\hline NTBO & $47 \mathrm{bB}$ & $116 \mathrm{aA}$ & $13 b$ & $16 b$ \\
\hline
\end{tabular}

Notes: CTBN $=$ conventional till malt barley with 67 to $134 \mathrm{~kg} \mathrm{~N} \mathrm{ha}^{-1}$. CTBO $=$ conventional till malt barley with $0 \mathrm{~kg} \mathrm{~N} \mathrm{ha}^{-1}$. NTB-P = no-till malt barley-pea with 67 to $134 \mathrm{~kg} \mathrm{~N} \mathrm{ha}^{-1}$. NTBN = no-till malt barley with 67 to $134 \mathrm{~kg} \mathrm{~N} \mathrm{ha}^{-1}$. NTBO $=$ no-till malt barley with $0 \mathrm{~kg} \mathrm{~N} \mathrm{ha}^{-1}$.

* Numbers followed by different lowercase letters within a column are significantly different at $p$ $=0.05$ by the least significant difference test.

†Numbers followed by different uppercase letters within a row are significantly different at $p=$ 0.05 by the least significant difference test.

\section{Acknowledgements}

We greatly appreciate the excellent support provided by Bryan Gebhard (biological science technician, USDA Agricultural Research Service [ARS], Northern Plains Agricultural Research Laboratory, Sidney, Montana) for the management and irrigation of field plots and Joy Barsotti and Chris Russell (biological science technicians, USDA ARS, Northern Plains Agricultural Research Laboratory, Sidney, Montana) for soil and plant sample collection and analysis in the laboratory. We also acknowledge for the partial financial support provided by USDA ARS GRACEnet project for this study.

\section{Disclaimer}

Mentioning the name of product is for the use of consumers only and does not necessarily contribute to an endorsement by USDA ARS. USDA ARS is an equal opportunity employer

\section{References}

Abeledo, L.G., D.F. Calderini, and G.L. Slafer. 2008. Nitrogen economy in old and modern malting barleys. Field Crops Research 106:171-178, https://doi.org/10.1016/j. fcr.2007.11.006

Clapp, C.E., R.R. Allmaras, M.F. Layese, D.R. Linden, and R.H. Dowdy. 2000. Soil organic carbon and ${ }^{13} \mathrm{C}$ abundance as related to tillage, crop residue, and nitrogen fertilizer under continuous corn management in Minnesota. Soil and Tillage Research 55:127-142, https://doi.org/10.1016/s0167-1987(00)00110-0.

Davis, R.L., J.J. Patton, R.K.Teal,Y.Tang, M.T. Humphreys, J Mosali, K. Girma, J.W. Lawles, S.M. Moges, A. Malapati, J. Si, H. Zhang, S. Deng, G.V. Johnson, R.W. Mullen, and W.R. Raun. 2003. Nitrogen balance in the Magruder plots following 109 years in continuous winter wheat. Journal of Plant Nutrition 8:1561-1580, https://doi. org/10.1081/pln-120022364.
Delgado, J.A., M.J. Shaffer, H. Lal, S.P. McKinney, C.M. Gross, and H. Cover. 2008. Assessment of nitrogen losses to the environment with a Nitrogen Trading Tool (NTT). Computer Electronics in Agriculture 63:193-206, https://doi.org/10.1016/j.compag.2009.12.007.

Eickhout, B., A.P. Bouwman, and H. van Zeijts. 2006. The role of nitrogen in world food production and environmental sustainability. Agriculture Ecosystem and Environment 116:4-14, https://doi.org/10.1016/j. agee.2006.03.009.

Franzluebbers, A.J. 2007. Integrated crop-livestock systems in the southeastern USA. Agronomy Journal 99:361-372, https://doi.org/10.2134/agronj2006.0076.

Gregorich, E.G., B.H. Ellert, C.F. Drury, and B.C. Liang. 1996. Fertilization effects on soil organic matter turnover and corn residue carbon storage. Soil Science Society of America Journal 60:472-476, https://doi.org/10.2136/ sssaj1996.03615995006000020019x.

Halvorson, A.D., and C.A. Reule. 2007. Irrigated no-till corn and barley response to nitrogen in northern Colorado. Agronomy Journal 99:1521-1529, https:// doi.org/10.2134/agronj2006.0356.

Halvorson, A.D., B.J.Wienhold, and A.L. Black. 2002.Tillage, nitrogen, and cropping system effects on soil carbon sequestration. Soil Science Society of America Journal 66:906-912, https://doi.org/10.2136/sssaj2002.0906.

Herrero, M., P.K. Thorton, A.M. Notenbaert, S. Wood, S. Masangi, H.A. Freeman, D. Bossio, J. Dixon, M. Peters, J. van de Steeg, J. Lynam, P.R. Parthasarathy, S. Macmillan, B. Gerard, J. McDermont, C. Sere, and M. Rosegrant. 2010. Smart investments in sustainable food productions: Revisiting mixed crop-livestock systems. Science 327:822-825, https://doi.org/10.1126/ science. 1183725

IPCC (Intergovernment Panel on Climate Change). 2014. Climate Change 2014: Synthesis Report. Contribution of Working Groups I, II and III to the Fifth Assessment Report of the Intergovernmental Panel on Climate Change. Geneva, Switzerland: Intergovernment
Panel on Climate Change. https://doi.org/10.1017/ cbo9781107415416.

Janzen, H.H., K.A. Beauchemin,Y. Bruinsma, C.A. Campbell, R.L. Desjardins, B.H. Ellert, and E.C. Smith. 2003. The fate of nitrogen in agroecosystems: An illustration using Canadian estimates. Nutrient Cycling in Agroecosystem 67:85-102, https://doi.org/10.1023/a:1025195826663.

Jastrow, J.D. 1996. Soil aggregate formation and the accrual of particulate and mineral associated organic matter. Soil Biology and Biochemistry 28:665-676, https://doi. org/10.1016/0038-0717(95)00159-x.

Karlsson, L.O.T., O. Andren, T. Katterer, and I. Mattsson. 2003. Management effects on top soil carbon and nitrogen in Swedish long-term experiments: Budget calculations with and without humus pool dynamics. European Journal of Agronomy 20:137-147, https:// doi.org/10.1016/s1161-0301(03)00083-2.

Korsaeth, A., and R. Eltun. 2000. Nitrogen mass balances in conventional, integrated, and ecological cropping systems and the relationship between balance calculations and nitrogen runoff in an 8-year field experiment in Norway. Agriculture Ecosystem and Environment 79:199-214, https://doi.org/10.1016/s0167-8809(00)00129-8.

Legg, J.O., and J.J. Meisinger. 1982. Soil nitrogen budgets. In Nitrogen in Agricultural Soils, ed. J. Stevenson, 503566. Agronomy Monograph 22. Madison, WI: Soil Science Society of America. https://doi.org/10.2134/ agronmonogr22.c14.

Lenssen, A.W., J.T. Waddell, G.D. Johnson, and G.R. Carlson. 2007. Diversified cropping systems in semiarid Montana: Nitrogen use during drought. Soil and Tillage Research 94:362-375, https://doi.org/10.1016/j. still.2006.08.012.

Littell, R.C., G.A. Milliken, W.W. Stroup, R.D.Wolfinger, and O. Schabenberger. 2006. SAS for mixed models. Cary, NC: SAS Institute Incorporated.

Meisinger, J.J., and G.W. Randall. 1991. Estimating nitrogen budgets for soil-crop systems. In Managing Nitrogen for Groundwater Quality and Farm Profitability, ed. R.F. Follet, 85-124. Madison, WI: Soil Science Society of America. https://doi.org/10.2136/1991. managingnitrogen.c5

Migliorati, M.D.A., M.J. Bell, P.R. Grace, D.W. Rowlings, C. Scheer, and A. Strazzabosco. 2014. Assessing agronomic and environmental implications of different $\mathrm{N}$ fertilization strategies in subtropical grain cropping systems on Oxisols. Nutrient Cycling in Agroecosystem 100:369-382, https://doi.org/10.1007/ s10705-014-9655-4.

Omay,A.B., C.W. Rice, L.D. Maddux, and W.B. Gordon. 1997. Changes in soil microbial and chemical properties under long-term crop rotation and fertilization. Soil Science Society of America Journal 61:1672-1678, https://doi. org/10.2136/sssaj1997.03615995006100060019x.

Pieri, L., F. Ventura, M. Vignudelli, and P. Rossi. 2011. Nitrogen balance in a hilly semi-agricultural watershed 
in northern Italy. Italian Journal of Agronomy 6:67-75, https://doi.org/10.4081/ija.2011.e12.

Ross, S.M., R.C. Izaurralde, H.H.Janzen, J.A. Robertson, and W.B. McGill. 2008. The nitrogen balance of three longterm agroecosystems on a boreal soil in western Canada. Agriculture Ecosystem and Environment 127:241-250, https://doi.org/10.1016/j.agee.2008.04.007.

Sainju, U.M. 2013. Tillage, cropping sequence, and nitrogen fertilization influence dryland soil nitrogen. Agronomy Journal 105:1253-1263, https://doi.org/10.2134/ agronj2013.0106.

Sainju, U.M. 2017. Determination of nitrogen balance in agroecosystems. MethodsX 4:199-208, https://doi. org/10.1016/j.mex.2017.06.001

Sainju, U.M., A.W. Lenssen, B.L. Allen, W.B. Stevens, and J.D. Jabro. 2016. Nitrogen balance in response to dryland crop rotations and cultural practices. Agriculture Ecosystem and Environment 233:25-32, https://doi. org/10.1016/j.agee.2016.08.023

Sainju, U.M., A.W. Lenssen, B.L. Allen, W.B. Stevens, and J.D. Jabro. 2018. Nitrogen balance in dryland agroecosystem in response to tillage, crop rotation, and cultural practice. Nutrient Cycling in Agroecosystem 110:467-483, https://doi.org/10.1007/s10705-018-9909-7.

Sainju, U.M., A.W. Lenssen, T. Caesar-TonThat, J.D. Jabro, R.T. Lartey, R.G. Evans, and B.L. Allen. 2012. Dryland soil nitrogen cycling influenced by tillage, crop rotation, and cultural practice. Nutrient Cycling in Agroecosystem 93:309-322, https://doi.org/10.1007/ s10705-012-9518-9.

Sainju, U.M., W.B. Stevens, T. Caesar-Tonthat, and C. Montagne. 2014. Nitrogen dynamics affected by management practices in croplands transitioning from conservation reserve program. Agronomy Journal 106:1677-1689, https://doi.org/10.2134/ agronj13.0481.

Schepers, J.S., and A.R. Mosier. 1991. Accounting for nitrogen in nonequilibrium soil-crop systems. In Managing Nitrogen for Groundwater Quality and Farm Profitability, ed. R.F. Follett, 125-137. Madison, WI: Soil Science Society of America. https://doi. org/10.2136/1991.managingnitrogen.c6.

Smil, V. 1999. Nitrogen in crop production: An account of global flows. Global Biogeochemical Cycling 13:647662, https://doi.org/10.1029/1999gb900015.

Stevenson, FJ. 1982. Origin and distribution of nitrogen in soils. In Nitrogen in Agricultural Soils, ed. FJ. Stevenson, 1-42. Agronomy Monograph 22. Madison, WI: Soil Science Society of America. https://doi.org/10.2134/ agronmonogr22.c1.

Varvel, G.E., and T.A. Peterson. 1990. Residual soil nitrogen as affected by continuous, two-year, and four-year crop rotations. Agronomy Journal 82:958-962, https://doi. org/10.2134/agronj1990.00021962008200050024x.

Wang, C., M. Dannenmann, R. Meier, and K. ButterbachBahl. 2014. Inhibitory and side effects of acetylene and sodium chlorate on gross nitrification, gross ammonification, and soil-atmosphere exchange of $\mathrm{N}_{2} \mathrm{O}$ and $\mathrm{CH}_{4}$ in acidic to neutral montane grassland soil. European Journal of Soil Biology 65:7-14, https://doi. org/10.1016/j.ejsobi.2014.08.006.

Watson, C.A., and D.Atkinson. 1999. Using nitrogen budgets to indicate nitrogen-use efficiency and losses from whole farm systems: A comparison of three methodological approaches. Nutrient Cycling in Agroecosystem 53:259_ 267, https://doi.org/10.1023/a:1009793120577. 